\title{
Semantyka ram: rozwój koncepcji i kierunki zastosowań
}

\section{Izabela Szymańska}

\author{
Uniwersytet Warszawskie
}

\section{Wstęp}

Celem artykułu jest przedstawienie rozwoju koncepcji semantyki ram (frame semantics), zapoczątkowanej przez Charlesa Fillmore'a w latach siedemdziesiątych XX wieku, oraz niektórych przykładów jej zastosowania. Semantyka ram jest często wzmiankowana i kojarzona z nazwiskiem Fillmore'a, nie zawsze jednak zwraca się uwagę, że Fillmore przeformułowywał pojęcie ramy i nie zawsze wskazuje się jasno, o którym rozumieniu tego terminu jest mowa. Spojrzenie na ewolucję pojęcia ramy w pracach Fillmore'a i opartych na nich zastosowaniach każe się zastanowić nad możliwościami reprezentacji znaczenia i nad związkiem takiej reprezentacji z celami, do jakich się jej używa.

Koncepcja semantyki ram ${ }^{1}$ wywodziła się częściowo z prac Fillmore’a nad Case Grammar, z których najbardziej znany jest artykuł Case for Case z 1968 roku. W pracy tej Fillmore wprowadza 'ramę czasownikową' (case frame), pomyślaną jako opis ról semantycznych (deep cases 'głębokie przypadki semantyczne') związanych ze schematami zdaniowymi i określających, jakie czasowniki mogą się w tych schematach pojawić. Aby prześledzić zmiany w rozumieniu pojęcia ramy w pracach Fillmore'a i uporządkować terminologię, nazwijmy tę koncepcję ramą- 0.2

Ramy - 0 miały charakteryzować systematyczne relacje między uczestnikami wydarzenia (takimi, jak np. Agens, Obiekt, Instrument, Cel), perspektywą jego prezen-

1 Termin „semantyka ram” będzie tu używany jako odpowiednik terminu frame semantics, przyjętego jako ogólne określenie koncepcji Fillmore’a, warto jednak pamiętać, że sam autor w różnych pracach używał różnej terminologii, co zostanie pokazane poniżej (por. też Tokarski, 2006, 37; Kieraś, 2008, 157-158). W pracach polskich spotyka się też terminy „semantyka ram interpretacyjnych” (Waszakowa, 1998; Tokarski, 2006; Kieraś, 2008) lub „semantyka ramowa” (Kalisz, 2001, 144-153).

2 Przyporządkowanie kolejnym wersjom ram w koncepcji Fillmore’a indeksów jest wyłącznie zabiegiem porządkującym dokonanym przez autorkę na potrzeby niniejszego artykułu. 
tacji i możliwymi językowymi sposobami jego zakodowania (Fillmore, 1968, 21-32; 1987, 30). Ramy - 0 reprezentowały językoznawcze użycie pojęcia 'ramy' w znaczeniu opisu kombinatorycznych własności predykatów (Fillmore, 2006, 615), jednak wyodrębnienie klas czasowników charakteryzowanych przez takie same ramy prowadziło do uznania ram za reprezentacje pewnych typów 'scen' czy 'sytuacji' motywujących własności semantyczne czasowników (Fillmore, 1987, 30; 2006, 616).

Fillmore $(2006,614-616)$ wskazuje, że semantyka ram łączy językoznawczą tradycję rozumienia 'ramy', reprezentowaną przez Case Grammar, z szerszym rozumieniem tego terminu zaczerpniętym z badań kognitywistycznych, m. in. z prac Marvina Minsky'ego nad reprezentacją wiedzy. ${ }^{3}$ 'Rama' w owym szerszym rozumieniu kognitywnym to sposób organizacji wiedzy pozwalającej człowiekowi interpretować nowe doświadczenia. Wydaje się, że w swoim rozwoju i różnych zastosowaniach semantyka ram pokazuje na zmianę jedną lub drugą stronę owej językowo-konceptualnej monety. Stąd w semantyce ram występują dwa pola (Fillmore, 2006, 620), tzn. badania nad semantyką leksykalną, szczególnie predykatów, i nad mechanizmem interpretacji wyrażeń w tekście.

\section{Semantyka rozumienia}

Z perspektywy interpretacyjnej semantyka ram stawia pytanie o relacje między tekstem a sposobem jego rozumienia przez odbiorcę w kontekście (Fillmore, 1985a, 231), w szczególności o to, jaka struktura wiedzy systematyzująca doświadczenie pozwala interpretować struktury językowe. Semantyka ram jest więc 'semantyką rozumienia' (U-semantics, semantics of understanding), którą Fillmore (1985a, 222) odróżnia od semantyki warunków prawdziwości (T-semantics, semantics of truth).

Semantyka rozumienia została zaproponowana jako alternatywa wobec teorii znaczenia opartych na formułowaniu warunków, które muszą być spełnione, aby wyrażenie było użyte prawidłowo lub było prawdziwe (checklist theories of meaning; Fillmore, 1975; Petruck, 1996, 3). Jednym z argumentów za podejściem alternatywnym są nieostre granice kategorii językowych; przytacza się tu m.in. znane przykłady takich słów, jak kawaler, wdowa, sierota czy śniadanie (Fillmore, 1977a, 67-70; 1977b/2003, 212-213; Petruck, 1996, 2; Tokarski, 2006, 41). Fillmore przyjmuje, że znaczenie powinno się opisywać jako odzwierciedlenie doświadczenia kategoryzowanego przez prototypy (odwołuje się tu do teorii Eleanor Rosch; Fillmore, 1977a, 55-57; 1987, 33). Użycie wyrażenia językowego w nowej sytuacji opisuje jako wynik porównania obecnego doświadczenia z wcześniejszymi doświadczeniami i decyzji, czy są one na tyle do siebie podobne, aby wyrażać je tymi samymi środkami językowymi. Wizja znaczenia i interpretacji tekstu oparta jest na złożonym systemie sche-

3 Minsky zaproponował 'ramę' jako sposób opisu interpretacji scen w percepcji wizualnej. Rama Minsky'ego jest modelem dynamicznego konstruowania scen przez serię operacji interpretujących $\mathrm{i}$ integrujących. W model taki wbudowana jest też wiedza o tym, jak obiekt może się zmieniać w czasie lub ze względu na zmianę perspektywy obserwatora (Gawron, 2008, 17-18). Istotnym aspektem modelu Minsky'ego, z którego czerpie analogie opis znaczenia, jest założenie, że obraz konstruowany przez umysł jest znacznie bogatszy niż sygnały wizualne, np. obiekty są traktowane jako całość konceptualna, mimo że niektóre ich aspekty nie są widoczne, a relacje w istocie niewidoczne mogą zostać wywnioskowane i wpasowane w ramę wizualną (Stockwell, 2006, 9). 
matów (sieci pojęć) organizujących aspekty ludzkiego doświadczenia i wchodzących z sobą w interakcje, których elementy mogą być także częściami innych schematów (Fillmore, 1975, 123). Jest to więc próba ustrukturyzowania bogactwa informacji, które aktywuje użycie poszczególnych wyrażeń językowych, bez redukowania znaczenia do zamkniętego zbioru własności (Gawron, 2008, 1-4).

\section{Ramy i sceny}

W początkowej koncepcji Fillmore'a (1975; 1977a) narzędziami opisu tak pojętego procesu interpretacji są ramy i sceny. Użycie tych dwu pojęć wydaje się odzwierciedlać konceptualno-językowy dualizm zainteresowań semantyki rozumienia. 'Scena' jest strukturą konceptualną/kognitywną, natomiast 'rama' strukturą językową. Fillmore (1975, 124; 1977a, 63; 1977b/2003, 210) definiuje 'scenę' bardzo szeroko, jako typowy scenariusz wyznaczany przez daną kulturę, spójny fragment ludzkich wierzeń, czynności, doświadczeń czy wyobrażeń, z których wiele jest nieanalizowalnych i musi być poznawane przez doświadczenie jako całości. Natomiast 'rama' to system wyborów językowych, np. zespoły jednostek leksykalnych czy wybór kategorii gramatycznej, które można powiązać z prototypowym przykładem sceny (Fillmore, 1975, 124; 1977a, 63). Nazwijmy ramę tak zdefiniowaną ramą-1 .

Proces zrozumienia i komunikacji polega na aktywacji $\mathrm{ram}_{-1}$ i scen, oraz zastosowaniu do niech operacji mentalnych, np. wypełniania pustych miejsc w schematach.

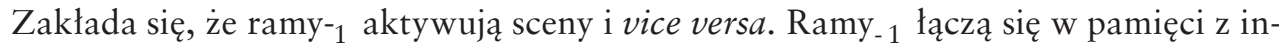
nymi ramami 1 przez wspólny materiał językowy; sceny łączą się ze scenami przez podobieństwo uczestniczących w nich obiektów i relacji albo kontekstu. Ramy ${ }_{-1}$ aktywują sceny istotne dla danego kontekstu; sceny mogą być częściowo zindywidualizowane, w zależności od wiedzy poszczególnych uczestników komunikacji (Fillmore, 1977a, 61; 1977b/2003, 212). ${ }^{4}$

W tak rozumianym procesie interpretacji tekstu aktywowanych jest oczywiście bardzo wiele scen, które się wzajemnie motywują, rozwijają i dodają szczegóły, co prowadzi do konstruowania scen większych i do stworzenia spójnej interpretacji tekstu (Fillmore, 1977a, 64-66). Proces ten jest nieco bardziej szczegółowo zilustrowany w artykule Fillmore'a (1977b), z którego pochodzi poniższy przykład:

(1) Harry paid this month's alimony with money borrowed from his stepdaughter (Fillmore, 1977b/2003, 241)

Harry zapłacił w tym miesiącu alimenty pieniędzmi pożyczonymi od swojej pasierbicy.

W interpretacji tego zdania słowo „alimenty” aktywuje sekwencję małżeństwo-rozwód, opartą na naszej wiedzy o działaniu prawa w danej kulturze (Fillmore, 1977b/2003, 239; zauważmy, że w różnych kulturach szczegóły takiej sceny mogą być różne). Fraza „w tym miesiącu” dodaje do sceny istotny szczegół, implikując, że

4 Fillmore (1977a, 66) motywuje rozróżnienie ram-1 i scen tym, że często elementy scen, nawet dobrze znanych i zrozumiałych nie mają dostępnych realizacji językowych w ramie-1 lub brak jest takich realizacji w systemie wiedzy poszczególnych użytkowników języka. Gdy takie wyrażenie się pojawi lub zostanie przyswojone przez użytkownika, zmienia się tylko rama-1, a nie scena. 
Harry został zobowiązany do płacenia ze wskazaną częstotliwością. Słowo „pożyczony" oznacza, że nastąpiła umowa: Harry otrzymał pieniądze i zobowiązał się je później zwrócić. Słowo „pasierbica” zakłada skomplikowaną relację czy zespół scen: Harry jest ponownie żonaty, a jego obecna żona była wcześniej zamężna i ma z tego małżeństwa córkę. Zauważmy przy okazji, że ta ostatnia interpretacja, podana przez Fillmore'a (1977b/2003, 241), opiera się na prototypie; słowa „pasierbica” użyjemy prawdopodobnie także $\mathrm{w}$ mniej prototypowych sytuacjach, np. gdy nie chodzi o żonę, lecz o obecną partnerkę Harry’ego, lub gdy żona/partnerka nie była wcześniej zamężna. „Pożyczone” implikuje, że Harry zawarł pewien rodzaj umowy, która będzie miała skutki w przyszłości. Elementy sceny muszą zostać dopasowane, aby odtworzyć relacje czasowe itd.

Dla porównania rozpatrzmy inny przykład:

(2) We never open our presents until the morning. (Fillmore, 1985a, 232)

Nigdy nie otwieramy prezentów wcześniej niż rankiem./Zawsze otwieramy prezenty dopiero rano.

W tym wypadku dla interpretacji zdania angielskiego zostanie prawdopodobnie aktywowana scena Bożego Narodzenia, ponieważ opisana sytuacja odpowiada wiedzy odbiorcy o typowych zwyczajach związanych z tym świętem, choć żadne z użytych tu wyrażeń nie jest charakterystyczne wyłącznie dla tej sceny (Gawron, 2008, 4). Przywołanie tego akurat kontekstu opiera się, co ważne, na wspólnym dla nadawcy i odbiorcy doświadczeniu kulturowym (Fillmore, 1985a, 232; zob. definicję 'sceny' powyżej). Widać to wyraźnie, gdy uświadomimy sobie, że polski odbiorca, interpretując polskie tłumaczenie tego zdania prawdopodobnie bez dodatkowych wyjaśnień nie odwoła się do natychmiast do Bożego Narodzenia, ponieważ otwieranie prezentów gwiazdkowych nie kojarzy mu się z porankiem, a z wieczorem wigilijnym.

Taka wizja rozumienia wyjaśnia więc, w jaki sposób interpretacja wykracza „daleko poza to co dosłownie powiedziane jest w tekście” (Gawron, 2008, 4) — dzieje się to zarówno dzięki aktywacji wiedzy przez poszczególne elementy językowe, jak w przykładzie (1), jak i przez dostrzeżenie relacji miedzy faktami, które ustanawia tekst, i porównanie ich z prototypem, jak w przykładzie (2).

\section{Encyklopedyczna wizja znaczenia}

Odtwarzane w ten sposób schematy opierają się na tzw. wiedzy pozajęzykowej, wiedzy o sposobie funkcjonowanie świata znajomego użytkownikowi danego języka. $\mathrm{Na}$ przykład odtworzenie sekwencji czasowej w przykładzie (1) opiera się na założeniu, że w danej kulturze obowiązuje małżeństwo monogamiczne, a interpretacja (2) na znajomości obyczajów utrwalonych w danej kulturze. Wskazuje to na istotną cechę fillmore'owskiej semantyki rozumienia, jaką jest encyklopedyczna wizja znaczenia ${ }^{5}$. Fillmore (1985a, 233, 252) nie wyznacza granicy między kompetencją 'językową' a wiedzą 'pozajęzykową', uznając, że ta ostatnia w sposób naturalny uczestniczy w in-

5 Cechę tę semantyka ram dzieli z innymi podejściami do języka, sytuującymi się w szerokiej orientacji kognitywnej, np. z gramatyką kognitywną Langackera (por. np. Langacker, 2008, 39; Kalisz, 2001, 44-48; Kardela, 2006, 199-201). 
terpretacji i że pewne jej elementy są skonwencjonalizowane w kategoriach językowych, a przedmiotem zainteresowania semantyki czyni proces interpretacji rozumiany całościowo.

Interakcja scen aktywowanych przez wyrażenia językowe (ramy - $_{-1}$ ) ma więc opisać skomplikowany proces konstruowania modelu fragmentu świata w umyśle użytkownika języka, który ma miejsce w czasie interpretacji tekstu (Fillmore, 1977a, 61). W procesie tym istotną rolę odgrywa wiedza pozajęzykowa, często warunkowana kulturowo. Sceny, rozumiane jako skonwencjonalizowane schematy, tworzą pewne przewidywania i pomagają użytkownikowi strukturyzować napływające informacje (Fillmore, 1977a, 61; Zawisławska, 1998, 36). Konstruowane sceny mogą jednak różnić się do pewnego stopnia, w zależności od indywidualnych doświadczeń i stanu wiedzy użytkowników języka oraz od kontekstu, stąd ten sam tekst może być zinterpretowany różnie przez różne osoby (Fillmore, 1977a, 61; 1977b/2003, 212, 242). Fillmore uznaje, że opisu semantycznego nie można oddzielić od badania użycia języka w kontekście (1977a, 72) i podkreśla, że w koncepcji semantyki rozumienia interpretacja zdań polega na łączeniu konwencjonalnego znaczenia bezkontekstowego z kontekstem językowym i pozajęzykowym (1985a, 233). Obrazowo rzecz ujmując, udana interpretacja polega więc na tym, że użytkownik języka ma do dyspozycji, w postaci kompetencji językowej, odpowiedź na pytanie „po co w języku istnieje kategoria reprezentowana przez dane wyrażenie?” i potrafi odpowiedzieć na pytanie „dlaczego mówiący wybrał tę formę w tym kontekście?” (Fillmore, 1985a, 234). Fillmore włącza więc do semantyki rozumienia aspekty tradycyjnie uważane za domenę pragmatyki, nie zakładając ścisłego podziału.

Warto podkreślić, że interpretacja tekstu w koncepcji Fillmore’a, choć wyjaśnia, jak rozumienie wykracza poza to, co zostało explicite powiedziane (por. przykłady (1) i (2)), oparta jest na aktywacji przez konkretny materiał językowy. W przykładzie (1) widać „otwieranie” skomplikowanych scen przez pojedyncze słowa; rolę taką pełnią jednak oczywiście także inne wybory językowe, np. użycie czasów gramatycznych czy przedimków oraz całe kombinacje „wywołujące” znane odbiorcy stereotypy, jak w przykładzie (2). Fillmore podkreśla (np. 1986, 56-58), że znaczenia są aktywowane przez rzeczywiście użyte $\mathrm{w}$ tekście formy, a interpretacja nie polega na tym, że „interpretujący wydobywają z tekstu to, co do niego wkładają"6 (1986, 50), którą to metodę ironicznie przypisuje niektórym badaczom literatury. Istotna jest tu ciągła interakcja struktur językowych i konceptualnych (Fillmore, 2006, 613-614).

\section{Rama jako struktura konceptualna}

W pracach z lat osiemdziesiątych XX wieku Fillmore odchodzi od pojęcia 'sceny'7 i definiuje ramę jako system pojęć powiązanych w taki sposób, że zrozumienie jednego z niech wymaga zrozumienia całego systemu, a wprowadzenie jednego takie-

6 Wszystkie cytaty podane są w moim tłumaczeniu.

7 Być może jedną z przyczyn była wielofunkcyjność tego pojęcia. Fillmore (1977b/2003, 250-251) wspomina, że scena otrzymała „zbyt wiele zadań”, skoro miała się odnosić m.in. zarówno do sytuacji rzeczywistych, jak i wyabstrahowanych z nich schematów tworzących wiedzę użytkownika języka, oraz do poszczególnych stadiów procesu interpretacji. 
go pojęcia do tekstu powoduje, że wszystkie inne stają się automatycznie dostępne (Fillmore, 1982, 111). Nazwijmy tę wersję ramą- 2 .

Rama $_{2}$ jest strukturą konceptualną, której elementy są indeksowane przez słowa i używane w procesie interpretacji (Petruck, 1996, 1). Można więc uznać, że rama 2 przejęła funkcje sceny (Fillmore, 1985a, 223). Relacja między wyrażeniami językowymi a strukturami konceptualnymi w procesie interpretacji jest jednak rozumiana tak samo: wyrażenia językowe użyte w tekście ewokują (ang. evoke) konwencjonalnie związane z nimi ramy $_{2}$, natomiast interpretujący przywołuje (ang. invoke) ramy , $_{-2}$ próbując dopasować zawartość tekstu do znanych mu niezależnie wzorów (Fillmore, 1985a, 232; 1986, 53). ${ }^{8}$

Nowa definicja ramy kładzie nacisk na to, że znaczenie słów rozpatruje się w relacji do sieci pojęć i że jest ono motywowane przez większe struktury konceptualne (Fillmore, 1985a, 223; Petruck, 1996, 1, 3). Często cytowanym przykładem ramy-2 (w pracach z lat siedemdziesiątych XX wieku opisywanym jako przykład 'sceny') jest 'transakcja handlowa' (Fillmore, 1977a, 58-59; 1977b/2003, 228; 1987, 32; Fillmore, Atkins, 1992, 78-79; Petruck, 1996, 1; Tokarski, 2006, 42), z którą związane są m. in. czasowniki kupować, sprzedawać, płacić, wydawać, kosztować. Użycie jednego z czasowników „wydobywa” pewien aspekt ramy i przedstawia wydarzenie z pewnej perspektywy, koncentrując się na niektórych spośród potencjalnych uczestników 'transakcji'. Opisanie tego fragmentu wiedzy jako ramy 2 oznacza, że zrozumienie każdego z czasowników wymaga rozumienia całości mechanizmu 'transakcji' i w związku z tym nie można rozumieć jednego, nie rozumiejąc wszystkich. Wiedza strukturyzowana przez ramę-2 stanowi motywację dla kategorii konceptualnych reprezentowanych przez słowa.

Innym znanym przykładem jest rama 'kalendarzowa' (Fillmore, Atkins, 1992, 77-78; Tokarski, 2006, 40). Interpretacja grupy wyrażeń związanych z tą ramą-2 (nazwy dni tygodnia, week, weekend, weekday, fortnight etc) wymaga - według Fillmore'a (1985a, 223-224) — wiedzy o:

(3) (a) naturalnym cyklu czasowym związanym z następowaniem po sobie dnia i nocy,

(b) konwencjonalnym cyklu siedmiodniowym,

(c) konwencjonalnym ustaleniu, kiedy jeden cykl się kończy a następny zaczyna,

(d) utrwalonym w danej kulturze zwyczaju przeznaczania pewnej części cyklu na pracę a pewnej na odpoczynek.

Przykład ten dobrze ilustruje encyklopedyczność semantyki ram i rolę konwencji kulturowych. W związku z ramą kalendarzową Tokarski $(2006,40)$ zwraca uwagę na ciekawe polskie użycia słowa weekend, np. dtugi weekend czy siedmiodniowy weekend, w których weekend nie znaczy 'sobota i niedziela', lecz 'seria dni wolnych od pracy’. Można wytłumaczyć takie użycia wysunięciem na pierwszy plan pewnego aspektu wiedzy odzwierciedlonej w organizacji ramy, w tym wypadku opozycji

8 'Rama-2' i 'scena' rozumiane jako całości pojęciowe są bliskie strukturom postulowanym w innych teoriach orientacji kognitywnej, takim jak 'skrypt', 'domena', 'scenariusz', 'schemat pojęciowy' czy 'gestalt' (Fillmore, 1977b/2003, 250-251; 1985a, 223; 1986, 49 ftn 1; Lakoff, 1987, 68; Burkhanov, 1999, 179; Hejwowski, 2004, 52; Stockwell, 2006; Gawron, 2008, 4). 
'praca-dni wolne'. Jest to dobra ilustracja wspomnianego już powiązania kategorii językowych z potrzebami komunikacyjnymi wspólnoty językowej (Fillmore, 1985a, 233-234). Dtugi weekend to przykład na to, że możliwości polskiej ramy zostały wykorzystane, gdy pojawiła się potrzeba nazwania wyrazistego w naszej kulturze zjawiska. Takie przypadki potwierdzają też, że często nowe pojęcia są niejako wbudowywane w istniejące już ramy (Gawron, 2008, 6).

Zarysowana tu wizja semantyki rozumienia jest bardzo obszerna i „mocna”, i stąd w pewnych aspektach wydaje się mało sprecyzowana. Widać to wyraźnie w podsumowaniu dokonanym przez samego Fillmore'a (1987, 34):

W modelu opisu, który wyłania się z powyższych rozważań, słowa i inne formy i kategorie językowe indeksują kategorie semantyczne czy kognitywne, które z kolei są częścią jakiegoś rodzaju większych struktur konceptualnych; wszystko to jest interpretowalne dzięki jakiejś wiedzy o rodzaju sytuacji czy kontekstów, na potrzeby których wspólnota [językowa] wytworzyła takie kategorie i udostępniła je swoim uczestnikom i o tle w postaci doświadczeń i obyczajów, które wytwarzają takie konteksty; kategorie te, konteksty i samo tło rozumiane są w kategoriach prototypów.

Wydaje się, że w pracach z lat siedemdziesiątych i osiemdziesiątych XX wieku na pierwszy plan wysuwa się zainteresowanie kognitywnym rozumieniem ramy-2 (wcześniej sceny) jako struktury wiedzy, próba określenia jej natury i jej wkładu w rozumienie tekstu. Fillmore wspomina na przykład, że „bardzo często rama czy tło, w odniesieniu do którego definiuje się słowo, rozumiane jest jako spora porcja otaczającej nas kultury" (1987, 33). Zasadne jest pytanie, czy tak obszerna wiedza biorąca udział w interpretacji wyrażeń językowych, szczególnie wiedza pozajęzykowa, czy kulturowa ma być reprezentowana w opisie językoznawczym. Fillmore (1985a, 233) ustosunkowuje się to tego problemu następująco: konieczne jest uwzględnienie udziału takiej wiedzy w opisie udziału poszczególnych leksemów i struktur gramatycznych w konstruowaniu interpretacji tekstu. Nie znaczy to, że semantyka ma opisywać całość takiej wiedzy, powinna jednak np. opisywać jej rolę w tworzeniu się kategorii znaczeniowych. Tak więc semantyka rozumienia zakłada, iż wiedza pozajęzykowa jest obecna implicite w skonwencjonalizowanych w danym języku kategoriach (co widać w koncepcji aktywizacji czy ewokowania wiedzy przez wyrażenia językowe), natomiast stopień szczegółowości jej reprezentowania nie jest ustalony. W istocie wydaje się on zależeć od bardziej szczegółowych celów, do których używa się takiej reprezentacji.

\section{Leksykalno-semantyczny aspekt ram}

Wczesną próbę ${ }^{9}$ uchwycenia „porcji” wiedzy tworzącej scenę znajdujemy w opisie 'transakcji handlowej' u Fillmore'a (1977b/2003, 229-232). W scenie 'transakcji'

9 U Fillmore’a (1977a i 1985a) znajdujemy jedynie ogólną dyskusję mechanizmów interpretacji, bez prób reprezentacji. Schematy w (4)-(6) zostały nieco zaadaptowane w stosunku do Fillmore'a 1977b/2003 ze względów graficznych. 
biorą udział cztery elementy: Buyer/Kupujący (A), Goods/Towar (B), Money/Pieniądze (C) i Seller/Sprzedający (D).

(4) Commercial event/Transakcja handlowa

\begin{tabular}{|ll|}
\hline A (buyer) & $B$ (goods) \\
C (money) & $D$ (seller) \\
\hline
\end{tabular}

Scena przedstawiona jest jako seria ‘slajdów' reprezentujących rozwój wydarzeń w czasie:

(5)

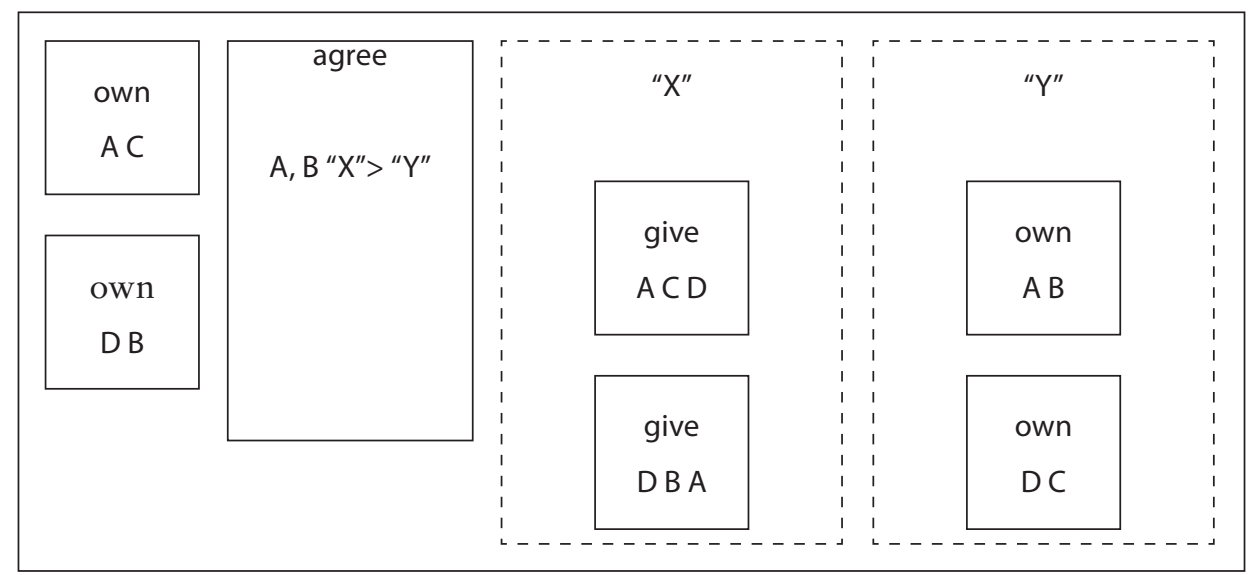

W pewnym momencie Kupujący A jest właścicielem pieniędzy C, a Sprzedający D jest właścicielem towaru B, co symbolizują dwa pierwsze kwadraty. Drugi 'slajd' oznacza, że A i B porozumiewają się, że wymiana tych obiektów między nimi, oznaczona "X", doprowadzi do przeniesienia własności, który to stan końcowy symbolizuje "Y". Tego rodzaju reprezentacja przedstawia ogólny schemat sytuacji, ujęty od strony konceptualizacji i doświadczeń użytkownika języka.

Natomiast gdy dochodzi do opisu poszczególnych czasowników jako elementów aktywizujących scenę, reprezentacja „przestawia” się na bardziej szczegółowy problem realizacji uczestników sceny w strukturze składniowej. ${ }^{10}$ Schematy w (6) mają pokazać, jak poszczególne czasowniki (buy/kupić, sell/sprzedać, pay/(za)płacić, spend/wydać, charge/policzyć, cost/kosztować) realizują składniowo poszczególnych uczestników, narzucając określoną perspektywę prezentacji sceny (pozostawiono angielskie przykłady, ponieważ chodzi tu o sposób realizacji składniowej w konkretnym języku):

10 Zagadnienia te, szczególnie interakcja czasowników ze strukturami składniowymi, stoją w centrum zainteresowania modelu siostrzanego wobec semantyki ram, mianowicie gramatyki konstrukcji - Construction Grammar, również wywodzącego się z prac Fillmore’a i nawiązującego w pewnych aspektach do semantyki ram (np. Fillmore, 1985b; 1988; Kay, Fillmore, 1999; Goldberg, 1995; 2003; 2006; Fried, Östman, 2004; omówienie w Szymańska, Śpiewak, 2006). 
(6)

\begin{tabular}{|c|c|c|c|}
\hline \multicolumn{2}{|c|}{ buy } & \multicolumn{2}{|c|}{ sell } \\
\hline $\begin{array}{c}\text { A } 1 \\
C \text { for }\end{array}$ & $\begin{array}{c}\text { B } 2 \\
\text { D from }\end{array}$ & $\begin{array}{l}\text { A to } \\
C \text { for }\end{array}$ & $\begin{array}{l}\text { B } 2 \\
\text { D } 1\end{array}$ \\
\hline \multicolumn{2}{|c|}{ pay } & \multicolumn{2}{|c|}{ spend } \\
\hline A 1 & B for & A 1 & B on \\
\hline C 2 & $D$ to & C 2 & [D] \\
\hline \multicolumn{2}{|c|}{ pay } & \multicolumn{2}{|c|}{ charge } \\
\hline A 1 & B for & A 2 & B for \\
\hline C & D 2 & C & D \\
\hline \multicolumn{2}{|c|}{ cost } & & \\
\hline A 3 & B 1 & & \\
\hline C & [D] & & \\
\hline
\end{tabular}

Cyfry 1, 2 i 3 odnoszą się do funkcji gramatycznych (podmiotu, dopełnienia bliższego i dalszego). Pogrubieniem oznaczone są elementy sceny, które dany czasownik wysuwa na pierwszy plan (foregrounds, puts into perspective), co w praktyce oznacza, iż w zdaniu czynnym z danym czasownikiem są one zrealizowane jako podmiot i dopełnienie. Nawiasy kwadratowe oznaczają elementy sceny, które nie mogą być wyrażone $\mathrm{w}$ zdaniu prostym z opisywanym czasownikiem.

Dla porównania, w późniejszym artykule (Fillmore, Atkins, 1992, 79) znajdujemy te informacje podane bardziej opisowo (dla strony czynnej, elementy składniowo opcjonalne $\mathrm{w}$ nawiasach, nawiasy kwadratowe - elementy, które mogą być opuszczone, gdy są kontekstowo 'znane', NULL - element nie występuje w zdaniach z tym czasownikiem, Subj - podmiot, D-Obj - dopełnienie bliższe, I-Obj - dopełnienie dalsze). Widać jednak, że chodzi o uchwycenie tego samego problemu, tzn. jak elementy konceptualizacji są systematycznie zakodowane w języku, czyli o ujęcie z punktu widzenia semantyki leksykalnej. ${ }^{11}$

(7)

\begin{tabular}{|c|c|c|c|c|}
\hline & Buyer & Seller & Goods & Money \\
\hline BUY & Subj & (from) & D-Obj & (for) \\
\hline SELL & (to) & Subj & D-0bj & (for) \\
\hline CHARGE & $(\mathrm{I}-0 \mathrm{bj})$ & Subj & (for) & D-0bj \\
\hline SPEND & Subj & NULL & for/on & D-0bj \\
\hline PAY & Subj & {$[\mathrm{l}-0 \mathrm{bj}]$} & {$[$ for $]$} & D-0bj \\
\hline PAY & Subj & (to) & For & D-0bj \\
\hline COST & $(\mathrm{I}-0 \mathrm{bj})$ & NULL & Subj & D-0bj \\
\hline
\end{tabular}

11 Zauważmy, że w (6) i (7) czasownik pay pojawia się dwukrotnie, ze względu na możliwość użycia go w zdaniach typu: They paid him $20 \$$ (for...) i They paid $20 \$$ to him (for...). W gramatyce konstrukcji problem ten można uchwycić przez interakcję jednego czasownika z dwiema różnymi konstrukcjami składniowymi. 
Wydaje się, że semantyczno-leksykalne ujęcie ramy wysuwa się na pierwszy plan odkąd koncepcję tę zaczęto stosować do badań leksykograficznych w latach dziewięćdziesiątych XX wieku (np. Fillmore, Atkins, 1992; Atkins, 1995; Petruck, 1995). W często cytowanym artykule z 1992 roku Fillmore i Atkins przedstawili bardzo subtelną analizę ramy konceptualnej 'ryzyka', w powiązaniu z realizacją językową jej elementów na przykładzie czasownika i rzeczownika risk (ryzykowaćlryzyko), opartą na użyciach tych słów zaświadczonych w korpusie. Wspomnijmy tylko, że rama 'ryzyka' jest bardziej skomplikowana od 'transakcji handlowej' i obejmuje następujące elementy: Harm (Szkoda), Victim (Ofiara), Valued Object (Cenny Obiekt), Risky Situation (Ryzykowna Sytuacja), Deed (leading to a risky situation) (Czyn (prowadzący do ryzykownej sytuacji)), Actor (Działający), Intended Gain (Zamierzona Korzyść), Purpose (Cel), Beneficiary (Odnoszący Korzyść) i Motivation (Motywacja). W związku z tym liczba możliwych kombinacji realizacji językowych owych elementów jest dość duża. Aby uświadomić sobie złożoność takiego opisu, przytoczmy tylko kilka przykładów (Fillmore, Atkins, 1992, 88, 89, 94):

(8) Why did he risk [his life] [for a man he did not know]?

Dlaczego zaryzykował życie dla człowieka, którego nie znał?

(Cenny Obiekt jako dopełnienie bliższe, Odnoszący Korzyść jako fraza przyimkowa)

She had risked [so much] [for the sake of vanity].

Zaryzykowała tak wiele dla próżności.

(Cenny Obiekt jako dopełnienie bliższe, Motywacja jako fraza przyimkowa)

We are prepared to risk [a substantial increase in unemployment] [in order to bring inflation to an end].

Jesteśmy gotowi zaryzykować duży wzrost bezrobocia, żeby stłumić inflację. (Szkoda jako dopełnienie bliższe, Cel jako zdanie bezokolicznikowe)

Artykuł o ramie 'ryzyka' przedstawił zarys metody tworzenia słownika opartego na ramach, potencjalnie dającego kompletny opis złożonych relacji między sensami jednostek leksykalnych przez rozróżnienie ewokowanych przez nie ram, obsługiwanego przez systemy komputerowe bez technicznych ograniczeń tradycyjnych słowników. Ten kierunek wykorzystania semantyki ram zaowocował powstaniem FrameNetu, projektu z zakresu leksykografii komputerowej, realizowanego w Berkeley od późnych lat dziewięćdziesiątych XX wieku.

\section{FrameNet jako sformalizowane zastosowanie semantyki ram}

Celem FrameNetu (m.in. Atkins, Fillmore, Johnson, 2003; Fillmore, Johnson, Petruck, 2003; Fillmore, Petruck, Ruppenhofer, Wright, 2003; Ruppenhoffer et al., 2006) jest ekstrakcja z elektronicznych korpusów tekstów informacji o własnościach semantycznych i składniowych słów w powiązaniu z elementami ram semantycznych, które słowa te indeksują. FrameNet czerpie z semantyki ram założenia, że znaczenia słów tworzą sieci, że słowa użyte w określonym kontekście ewokują ramy i że różne znaczenia słowa odpowiadają różnym ramom, w których może ono uczestniczyć. 
Głównym przedmiotem zainteresowania FrameNetu jest semantyczna motywacja własności kombinatorycznych słów. Reprezentacja framnetowa opisuje semantyczno -składniową walencję jednostki leksykalnej przez wyszczególnienie elementów ramy (ról uczestników) ewokowanej przez słowo, typów fraz realizujących role i ich funkcji gramatycznych (Fillmore, Johnson, Petruck, 2003, 237-238). FrameNet opisuje też relacje między ramami, ujęte w hierarchie dziedziczenia.

Dane framenetowe oprócz celów leksykograficznych mogą być wykorzystywane do badań nad polisemią (Boas, 2001), kolokacjami, relacjami struktury semantycznej i składniowej, przetwarzaniem języka naturalnego (NLP - Natural Language Processing), inferencjami, a w dalszej perspektywie być może do tłumaczenia maszynowego (Fillmore, Johnson, Petruck, 2003, 249). Istnieje kilka projektów zastosowania metodologii FrameNetu do innych języków poza angielskim; próby dla języka polskiego podjęto w Zakładzie Językoznawstwa Komputerowego Uniwersytetu Warszawskiego (projekt „Ramki”; zob. też Kieraś, 2008).

Nie będziemy tu wchodzić w szczegóły techniczne FrameNetu (zob. np. Ruppenhoffer et al., 2006), w świetle powyższych rozważań interesujące jest jednak, jak wygląda rama w reprezentacji w dużym stopniu sformalizowanej. Rama na potrzeby FrameNetu to „schematyczna prezentacja typu sytuacji, która leży u podstaw znaczenia słowa (lub grupy słów), z wyodrębnieniem ról uczestników lub aspektów sytuacji, które nazywamy elementami ramy" (Fillmore, Petruck, Ruppenhofer, Wright, 2003, 305). Uściślony wariant framenetowy moglibyśmy nazwać ramą-3. Rama ${ }_{-3}$ nawiązuje w pewnym stopniu do ramy 0 , choć jest bardziej szczegółowa i inaczej ujmuje kwestię ról semantycznych.

Dla przykładu opis ramy 3 Attaching (Przyłączanie) wygląda następująco (podkreślone są elementy ramy):

(8) An Agent attaches an Item to a Goal, generally by manipulating a Connector, such that the Item is fixed to the Goal. Alternatively, a Agent uses a Connector to attach two Items to each other, where each serves as a Goal for the other. In either case, the Connec$\underline{\text { tor, }}$ if present, remains to bind the Item or Items. This asymmetric or symmetric relationship profiles the parts and has them remain as parts, without creating a new entity. (Fillmore, Petruck, Ruppenhofer, Wright, 2003, 307) 12

Dalej następują przykłady składniowej realizacji poszczególnych elementów ramy (tu Agent/Agens, Item/Obiekt, Goal/Cel, Connector/Łącznik) w zdaniach z czasownikami związanymi z tą ramą (np. tie 'związać') oraz ograniczeń semantycznych związanych z poszczególnymi elementami ramy (np. ożywiony/nieożywiony). Warto zwrócić uwagę, że używane we FrameNecie nazwy ról uczestników sytuacji są szczegółowe i związane z rodzajem sytuacji, a nie pochodzą ze z góry ustalonego małego zbioru (np. ról semantycznych typu Agent/Agens, Patient/Pacjent, Instru-

12 „Agens przyłącza Obiekt do Celu, na ogół przy użyciu Łącznika, tak że Obiekt zostaje przymocowany do Celu. Agens może też użyć Łącznika, aby połączyć ze sobą dwa Obiekty, które wtedy są Celami dla siebie nawzajem. W każdym przypadku Łącznik, jeśli jest obecny, trwale wiąże Obiekt lub Obiekty. Ta symetryczna lub asymetryczna relacja profiluje części i pozostawia je jako części, nie tworząc nowej rzeczy." 
ment/Instrument, Recipient/Otrzymujący), choć mogą się z tym zbiorem zazębiać (Fillmore, 2006, 616). Przykład ten dobrze pokazuje też, że w opisie framenetowym celem jest rozłożenie sytuacji na elementy, które będą się systematycznie pojawiać w zdaniach, a więc najistotniejsze są tu semantyczne korelaty składniowej walencji. Dlatego najważniejszym aspektem jest opis predykatów, w szczególności czasowników. FrameNet obejmuje też jednostki leksykalne innych kategorii, jednak opis np. wielu rzeczowników ma na celu przed wszystkim uchwycenie, z jakimi predykatami najczęściej się one łączą i jak funkcjonują jako elementy ram ewokowanych przez predykaty (Ruppenhoffer et al., 2006, 6), a co za tym idzie, w jakie struktury mogą wchodzić. Petruck $(1996,5)$ wskazuje, że rzeczowniki znacznie trudniej ująć w opisie ramowym niż czasowniki.

Dla przykładu spójrzmy na opis ramy kalendarzowej z FrameNetu, która zawiera wyłącznie rzeczowniki (ok. 60 jednostek leksykalnych; podkreślone są elementy ramy):

(10) Words in this frame name the different parts of the calendric cycle, both man-made and natural. Frame elements include Whole for the whole of which the target is a part, Relative Time (RelT) for locating the time with respect to an identifiable reference point, and Name for the name of the day (month, etc.) of a specially named unit.

Words in this frame figure into a variety of temporal schemas, realized as constructions. There are families of constructions in which these words occur, including ones in which weekday names combine with day part names using particular prepositions (e.g. on Wednesday morning, cf. on Wednesday, but in the morning) and ones in which calendric terms fill the slots in multi-word expressions such as N-after-N (e.g. day after day), N-by-N (e.g. week by week), N-to-N (e.g. month to month), etc. [...] Note, also, the connection between this frame and Iteration, specifically that many iterative adjectives and adverbs are based on calendric terms (e.g. daily, weekly, monthly, etc. $)^{13}$

(http://framenet.icsi.berkeley.edu/index.php?option=com_wrapper\&Itemi $\mathrm{d}=118 \&$ frame $=$ Calendric_unit\&)

Zauważmy, że większa część tego opisu (po pierwszym akapicie) poświęcona jest składniowym możliwościom kombinatorycznym rzeczowników określających jednostki kalendarzowe, które nie są predykatami. ${ }^{14}$ Widać tu bardzo wyraźnie sku-

13 „Słowa z tej ramy nazywają części cyklu kalendarzowego, zarówno wyznaczone przez człowieka, jak i naturalne. Elementy ramy to Całość, oznaczająca całość, której dana jednostka jest częścią, Czas Względny, który umieszcza element w relacji do oznaczonego punktu odniesienia, i Nazwa, oznaczająca nazwę dnia (miesiąca itd.) w przypadku jednostek specjalnie nazwanych. Słowa tej ramy pojawiają się w wielu schematach czasowych, realizowanych jako konstrukcje. Istnieją grupy konstrukcji, w których te słowa się pojawiają, m.in. takie, w których nazwy dni tygodnia łączą się z nazwami części dnia za pomocą określonych przyimków (np. on Wednesday morning, on Wednesday, ale in the morning) i takie, w których terminy kalendarzowe wypełniają schematy wielowyrazowe, takie jak N-after-N (np. day after day), N-by-N (np. week by week), N-to-N (np. month to month) itd. [...] Należy zauważyć powiązanie tej ramy z ramą 'Powtarzanie', ze względu na to, że wiele przymiotników i przysłówków iteratywnych wywodzi się od terminów kalendarzowych (np. daily, weekly, monthly itd.)”.

14 Ponieważ w tym przypadku relacja między jednostką leksykalną należącą do ramy a elementami ramy nie jest tak oczywista, jak w przypadku czasowników, poniżej podane są przykłady realizacji elemen- 
pienie opisu framenetowego na konkretnych sposobach realizacji elementów ramy w danym języku, które są oczywiście kluczowe z punktu widzenia celów leksykograficznych (Fillmore, Petruck, Ruppenhofer, Wright, 2003, 305). Również z punktu widzenia metody, najbardziej systematyczną możliwością jest „wejście” do ramy przez pojedyncze słowa i uchwycenie właściwości semantycznych znajdujących odzwierciedlenie w składni. Wydaje się więc, że we FrameNecie na pierwszy plan wysuwa się semantyczno-leksykalne, walencyjne rozumienie ramy i perspektywa produkcji, a nie interpretacji wyrażeń językowych. Co ciekawe, Fillmore i Baker (2001) wskazują, że dane walencyjne z FrameNetu są przydatne do analizy interpretacji tekstu w ograniczonym zakresie i raczej pośrednio, co również sygnalizuje pewne przesunięcie zainteresowań FrameNetu w stosunku do semantyki rozumienia.

Powracając do zagadnienia ramy jako struktury wiedzy motywującej wyrażenia językowe, moglibyśmy porównać pierwszy akapit z (10) z nieformalnym oczywiście $\mathrm{i}$ intuicyjnym opisem przytoczonym $\mathrm{w}$ (3). Zauważmy, że w opisie framenetowym nie ma mowy o opozycji między pracą a czasem wolnym od pracy, czyli jeśli nawet jest ona istotna dla zrozumienia niektórych słów z tej ramy (np. weekend i weekday), to jest całkowicie implicytna. Znaczenie słowa weekend, aby powrócić do poprzednio wspomnianego przykładu, zdefiniowane jest jako 'sobota i niedziela' (Saturday and Sunday), co nie wyjaśnia dlaczego ta akurat cześć cyklu ma swoją osobną nazwę. Wskazuje to, że zakres owej „wiedzy o świecie” leżącej u podstaw znaczenia słów i koniecznej do ich opisu trudno ustalić, jeśli nie odzwierciedla się ona w ich możliwościach kombinatorycznych.

Powraca więc pytanie o kryteria pozwalające uznać, że dana „porcja” wiedzy zorganizowana jest w ramę, czyli o sposób wyznaczania granic ramy. W pracach Fillmore'a $\mathrm{z}$ lat siedemdziesiątych i osiemdziesiątych XX wieku zagadnienie to nie pojawiało się; w artykule z 1996 roku Petruck $(1996,6)$ uznała je za jedno z zagadnień semantyki ram, oczekujących na dopracowanie. Jak można się spodziewać, sposób wyznaczania granic ram wypracowano w metodologii FrameNetu, przechodząc od konfrontowania intuicji badaczy z danymi z korpusu do kryteriów bardziej uściślonych (Fillmore, Petruck, Ruppenhoffer, Wright, 2003, 299-307; Ruppenhoffer et al., 2006, 11-18), opartych, zgodnie z ogólną tendencją we FrameNecie, na własnościach słów. Dla przykładu, przyjmuje się, że jednostki leksykalne grupowane w jedną ramę-3 powinny reprezentować taką samą liczbę i typ elementów ramy, typ aspektowy opisywanego wydarzenia i perspektywę prezentacji (profilowanie elementów jako funkcji gramatycznych). Ten ostatni czynnik powoduje np., że 'transakcja handlowa' jest opisana we FrameNecie przez kilka 'pod-ram' związanych z poszczególnymi czasownikami (które, jak już było wspomniane, prezentują wydarzenie z perspektywy różnych uczestników) i połączonych przez uogólniony 'scenariusz' (Ruppenhoffer et al., 2006, 16). Takie rozróżnienie w istocie przypomina sposób opisu pokazany w przykładach (5)-(6), powraca tu więc bardziej ogólna, nieustrukturyzowana językowo konceptualizacja, podobna do 'sceny/ramy ${ }_{2}$ ' (zob. też Fried, 2005, 283-289). Fillmore $(2006,616)$ wspomina, że we FrameNecie można w praktyce odróżnić

tów ramy kalendarzowej nazwanych Relative Time, Whole i Name (kursywą wyróżniono jednostki leksykalne należące do ramy kalendarzowej): Jo's mother will visit [RelT this coming] Tuesday. Jo fled in the early morning [Whole of Sunday December 15]. [Name Labor] Day is just around the corner. (http://framenet.icsi.berkeley.edu/index.php?option $=$ com_wrapper\&Itemid $=118 \&$ frame $=$ Calendr ic_unit\&). 
„małe” ramy związane z poszczególnymi predykatami, i „duże” ramy odnoszące się do skonwencjonalizowanych sytuacji (np. 'urodziny' czy 'proces kryminalny'), być może więc opis w ramach FrameNetu będzie rozwijał się w kierunku wielopoziomowych sieci struktur różnego rodzaju. Wydaje się więc, że wspomniany na początku dualizm towarzyszy semantyce ram także i w jej najnowszym wydaniu, sformalizowanym na potrzeby leksykografii komputerowej.

\section{Inne kierunki zastosowań semantyki ram}

FrameNet jest sformalizowanym zastosowaniem niektórych założeń semantyki ram do celów leksykograficznych. Fillmore $(2006,620)$ wskazuje jednak wyraźnie, że semantyka ram ma dwa nurty — bardziej formalny, związany ze żmudnym analizowaniem korpusu i opisywaniem jednostek leksykalnych we FrameNecie i bardziej interpretacyjny, skierowany na badanie efektów wywoływanych przez użycie poszczególnych wyrażeń w tekstach. Można sądzić, że jest to także odbicie dualizmu w rozumieniu ramy, ponieważ dla tego drugiego kierunku zastosowania bardziej przydatna wydaje się niesformalizowana i potencjalnie bardzo pojemna rama - $_{2}$ (czy też scena) z koncepcji semantyki rozumienia, obejmująca aspekty pragmatyczne, kontekstowe i kulturowe.

Pojęcie ramy - $_{2}$ bywa ciekawie wykorzystywana w szeroko pojętej lingwistyce tekstu do opisu mechanizmów interpretacji i udziału w nim wiedzy pozajęzykowej. Aby przywołać polskie przykłady, Waszakowa (1998) analizuje za pomocą ram - $_{2}$ neologizmy z tekstów prasowych, a więc wyrażenia powstałe na potrzeby opisu bieżącej sytuacji, których interpretacja wymaga znajomości szerokiego kontekstu oraz rozszyfrowania konotacji. ${ }^{15}$ Zrozumienie wyrażenia turystyka aborcyjna, które już zadomowiło się w polszczyźnie, wymaga np. wiedzy o różnym statusie prawnym aborcji w różnych krajach, odczytania wartościujących konotacji słowa aborcja w polskim kontekście i zastosowania tylko pewnego aspektu pojęcia turystyka. Jeśli więc, zgodnie z analizą Waszakowej $(1998,27)$, interpretacja odwołuje się tu do dwu ram, ramy te muszą dawać dostęp do znacznie obszerniejszej wiedzy niż wiedza abstrahowana z walencji, jak we FrameNecie, a w szczególności muszą obejmować konotacje.

Podobny przykład znajdujemy u Zawisławskiej (1998), która stosuje ramy-2 w analizie wiersza Jana Andrzeja Morsztyna Ogród mitości. Metafora organizująca ten utwór polega na opisaniu miłości przez pojęcia dotyczące ogrodu, a więc na aktywacji dwóch ram ${ }^{16}$. Interesujące jest to, że w tekście ${ }^{17}$ nie pada słowo miłość, kochać, ani żaden ich derywat, a ramę miłości ma tu aktywizować wzmianka o Kupidynie 18 i jego atrybutach: łuku i strzałach. Chodzi tu więc znów o ramę odwołującą się do

15 Przez konotacje rozumie się tu dodatkowe, niedefinicyjne treści, np. wartościowanie, kojarzone z wyrazem przez użytkowników danego języka.

16 Fillmore (1977a, 70-71; opis ten pochodzi z fazy ram-1 i scen) opisuje metaforę jako użycie ramy-1 (czyli wyrażenia językowego) konwencjonalnie związanego z pewną sceną w kontekście innej sceny. Jest to w zasadzie wizja metafory analogiczna do przedstawianej przez gramatykę kognitywną.

17 Poza tytułem, który pochodzi od wydawcy, nie od autora wiersza (Zawisławska, 1998, 37).

18 Lehrer (1992, 125-127), odwołując się podejścia ramowego, sugeruje, że znaczenie i użycie nazw własnych opiera się na ich własnościach pragmatycznych, wywoływanych przez nie konotacjach i aktywowanej przez nie wiedzy pozajęzykowej. Wydaje się, że niektóre nazwy własne muszą aktywować 
wiedzy kulturowej, symboliki i konotacji. Analizy tego rodzaju, intuicyjnie bardzo atrakcyjne, każą jednak zastanowić się, na jakiej podstawie postuluje się ramy używane dla wyjaśnienia zjawisk w konkretnym tekście. Z pewnością nie są one oparte na kryteriach podobnych do tych używanych we FrameNecie, raczej na intuicyjnych asocjacjach słów (zob. listy leksemów kojarzących się z miłością i z ogrodem, Zawisławska, 1998, 40) ${ }^{19}$, a uściślenie ich zakresu wydaje się bardzo trudne, szczególnie, że mają to być w założeniu struktury dynamiczne, do pewnego stopnia przekształcane w procesie interpretacji, a także częściowo zindywidualizowane ${ }^{20}$, o czym była mowa w podrozdziale 4. Ta ostatnia kwestia jest intuicyjnie bardzo wyrazista, gdy rozpatruje się proces interpretacji. Można założyć np., że niektórzy użytkownicy języka nie mają Kupidyna i jego atrybutów „podłączonych” do 'ramy miłości', i dlatego, czytając analizowany wiersz, nie wytworzą struktury metaforycznej i zinterpretują go inaczej lub nie zinterpretują w ogóle. Wskazuje to na kolejną różnicę w 'interpretacyjnym' i ‘leksykalno-semantycznym' rozumieniu ramy: uściślone ramy typu framenetowego nie pozostawiają marginesu indywidualnego, i z natury swej opisują zjawiska systemowe w języku.

W nurcie interpretacyjnym mieszczą się też zastosowania semantyki ram $\mathrm{w}$ analizie i krytyce tłumaczenia (nie mówimy tu o tłumaczeniu maszynowym), wykorzystujące potencjalnie dużą 'pojemność' $\mathrm{ram}_{-2}, / \mathrm{scen}$. W tym wypadku bardzo istotny jest aspekt uwarunkowania kulturowego i różnic kulturowych (Fillmore, 1977a, 64; 1985a, 232). Potencjał semantyki ram w tej dziedzinie sygnalizują przykłady typu (2). Ramy ${ }_{-1}$ i sceny, jako aktywujące się nawzajem struktury językowe i kognitywne, które nie wyznaczają granicy między wiedzą językową a kulturową ani semantyczną i pragmatyczną, są bardzo atrakcyjnym narzędziem do przedstawienia procesu tłumaczenia jako złożonego aktu interpretacji i komunikacji w kontekście, pozwalają bowiem integrować różne aspekty tak rozumianego tłumaczenia $\mathrm{w}$ ramach całościowego systemu wiedzy. Można np. wyjaśniać nietrafność użycia pewnych wyrażeń przez tłumacza lub analizować motywy pewnych decyzji, odwołując się do różnic kulturowych w organizacji scen/ram -2 (Rojo López, 2002; zob. też interesujący przykład ramy 'palenia' w różnych językach w Burkhanov, 1999). Oczywiście problem wyznaczenia ram pojawia się i tu, gdy próbuje się szczegółowej analizy tekstu tłumaczonego $^{21}$. W przypadku zastosowań $\mathrm{w}$ przekładoznawstwie najistotniejszy wydaje się jednak właśnie ogólny potencjał semantyki rozumienia, szczególnie to, że pozwala ona językowi „sięgać” w domenę doświadczeń kulturowych i wiedzy implicytnej (Neubert, Shreve, 1992, 65). Wydaje się, że ramy ${ }_{-1}$ i sceny lub ramy ${ }_{-2}$ potencjal-

skomplikowane systemy wiedzy i „spore porcje kultury” potrzebne do ich interpretacji, zróżnicowane u różnych użytkowników tego samego języka, nieistotne z punktu widzenia ram-3.

19 Sugeruje to fakt, że we FrameNecie rzeczownik garden ('ogród') należy do ramy Lokalizacje-wedługfunkcji (Locale-by-use, http://framenet.icsi.berkeley.edu/index.php?option=com_wrapper\&Itemid= $118 \&$ frame=Locale_by_use\&) a czasownik love ('kochać) do ramy Doznający-podmiot (Experiencer-subj, http://framenet.icsi.berkeley.edu/index.php?option=com_wrapper\&Itemid $=118 \&$ frame $=\mathrm{E}$ xperiencer_subj\&), a żadne z tych słów nie ma „swojej”, bardziej wyspecjalizowanej ramy. Jest to kolejna wskazówka, że rama-3 we FrameNecie rozumiana jest nieco inaczej niż rama-2 w semantyce rozumienia, na której opierają się wspomniane analizy.

20 Założenie, że ramy mogą być przekształcane w procesie interpretacji i że są częściowo zindywidualizowane przyjmuje też Lambrecht $(1984,782-792)$, analizując akceptowalność częściowo produktywnych idiomów.

21 Zauważa to Rojo López (2002, 346-347) w odniesieniu do własnej analizy. 
nie opisują wiedzę potrzebną do interpretacji tekstu w kontekście w sposób bardzo zbieżny z potrzebami teorii i krytyki tłumaczenia, szczególnie modeli funkcjonalnych (Snell-Hornby, 2005; 2006, 107-108), komunikacyjnych (Hejwowski, 2004, 49-59) czy tekstowych (Neubert, Shreve, 1992, 60-68). Snell-Hornby (2005, 194-195; 2006, 110-111) uznaje ramy - $_{1}$ i sceny za jedną z najbardziej inspirujących koncepcji językoznawczych, które znalazły zastosowanie w translatoryce. Nieprzypadkowe jest to, że na ogół analizy przekładowe odwołują się do $\mathrm{ram}_{-1}$ i scen lub ram-2, nie do ramy $_{-3}$ ukierunkowanej na walencję, które przeważa we FrameNecie; jest to kolejne potwierdzenie dualizmu w rozumieniu ramy.

\section{Zakończenie}

Powyższa próba prześledzenia rozwoju semantyki ram pokazuje jej wielki potencjał opisowy i złożoność zamierzonego opisu, niezależnie od tego, czy głównym przedmiotem zainteresowania czyni się mechanizm interpretacji tekstu, czy semantykę leksykalną (Gawron, 2008, 8). Różnice, które można zauważyć w poszczególnych 'fazach' czy nurtach semantyki ram wynikają z różnicy perspektywy i celów: nurt leksykalno-semantyczny, reprezentowany współcześnie przez FrameNet, wiąże się bardziej z perspektywą kodowania i z badaniem semantycznej motywacji składniowego zachowania słów, natomiast nurt interpretacyjny, dominujący w koncepcji semantyki rozumienia, koncentruje się na perspektywie dekodowania i na strukturze wiedzy aktywowanej przez język w konkretnej sytuacji jego użycia. Zmienna koncepcja ramy dobrze więc ilustruje zależność między funkcjonowaniem pojęcia językoznawczego i projektowaniem zakresu reprezentacji semantycznej a celami opisowymi, do jakich się je wykorzystuje.

\section{Bibliografia}

Atkins, B.T.S., 1995, The role of the example in a frame semantics dictionary, [in:] M. Shibatani, S. Thompson (ed.), 25-297.

Atkins, S., Ch. J. Fillmore, C. R. Johnson, 2003, Lexicographic Relevance: Selecting Information From Corpus Evidence, "International Journal of Lexicography" 16(3), 251-280.

Bach, E., R. T. Harms (ed.), 1968, Universals in Linguistic Theory, New York: Holt, Rinehart and Winston.

Bartmiński, J., B. Boniecka (red.), 1998, Tekst. Analizy i interpretacje, Lublin: Wydawnictwo UMCS.

Boas, H. C., 2001, Frame Semantics as a framework for describing polysemy and syntactic structures of English and German motion verbs in contrastive computational lexicography, http://framenet.icsi.berkeley.edu/papers/boasCL2001.pdf (9.11.2007).

Brown, K. (ed.), 2006, Encyclopedia of Language and Linguistics (2nd ed.), Elsevier Ltd.

Burkhanov, I., 1999, Smoking and other frames: Applications in ideography, [in:] B. Lewandowska-Tomaszczyk (ed.), Cognitive Perspectives on Language, Frankfurt am Main: Peter Lang, 177-186.

Dam, H. V., J. Engberg, H. Gerzymisch-Arbogast (ed.), 2005, Knowledge Systems and Translation, Berlin and New York: Mouton de Gruyter.

Dirven, R., G. Radden (ed.), 1987, Concepts of Case, Tübingen: Gunter Narr Verlag.

Fillmore, Ch. J., 1968, The Case for Case, [in:] E. Bach, R. T. Harms (ed.), 1-88. 
Fillmore, Ch. J., 1975, An Alternative to Checklist Theories of Meaning, "Proceedings of the Annual Meetings of Berkeley Linguistics Society” 1, 123-131.

Fillmore, Ch. J., 1977a, Scenes-and-frames semantics, [in:] A. Zampolli (ed.), 55-81.

Fillmore, Ch. J., 1977b, Topics in Lexical Semantics, [in:] Ch. J. Fillmore, 2003, 201-260.

Fillmore, Ch. J., 1982, Frame Semantics, [in:] The Linguistic Society of Korea (ed.), 111137.

Fillmore, Ch. J., 1985a, Frames and the semantics of understanding, "Quaderni di semantica" 6(2), 222-254.

Fillmore, Ch. J., 1985b, Syntactic Intrusions and the Notion of Grammatical Construction, "Proceedings of the Annual Meetings of Berkeley Linguistics Society" 11, 73-86.

Fillmore, Ch. J., 1986, U-semantics. Second round, "Quaderni di semantica" 7(1), 49-58.

Fillmore, Ch. J., 1987, A Private History of the Concept 'Frame', [in:] R. Dirven, G. Radden (ed.), 28-36.

Fillmore, Ch. J., 1988, The Mechanisms of Construction Grammar, "Proceedings of the Annual Meetings of Berkeley Linguistics Society" 14, 35-55.

Fillmore, Ch. J., 2003, Form and Meaning in Language. Volume 1: Papers on Semantic Roles, Stanford: CSLI Publications.

Fillmore, Ch. J., 2006, Frame Semantics, [in:] K. Brown (ed.), vol. 4, 613-620.

Fillmore, Ch. J., B. T. Atkins, 1992, Towards a frame-based lexicon: The semantics of RISK and its neighbours, [in:] A. Lehrer, E. Feder Kittay (ed.), 75-102.

Fillmore, Ch. J., C. F. Baker, 2001, Frame Semantics for Text Understanding, http://framenet.icsi.berkeley.edu/index.php?option $=$ com_content $\&$ task $=$ view\&id $=39 \&$ Itemid $=42$ (3.04.2008).

Fillmore, Ch. J., C. R. Johnson, M. R. L. Petruck, 2003, Background to FrameNet, "International Journal of Lexicography" 16(3), 235-250.

Fillmore, Ch. J., M. R. L. Petruck, J. Ruppenhofer, A. Wright, 2003, FrameNet in Action: The Case of Attaching, "International Journal of Lexicography" 16(3), 297-332.

Fried, M., 2005, A frame-based approach to case alternations: the swarm-class verbs in Czech, "Cognitive Linguistics” 16(3), 475-512.

Fried, M., J.-O. Östman, 2004, Construction Grammar: A thumbnail sketch, [in:] M. Fried, J.-O. Östman (ed.), 11-86.

M. Fried, J.-O. Östman (ed.), 2004, Construction Grammar in a Cross-Language Perspective, Amsterdam and Philadelphia: John Benjamins.

Hejwowski, K., 2004, Kognitywno-komunikacyjna teoria przekładu, Warszawa: Wydawnictwo Naukowe PWN.

Gawron, J. M., 2008, Frame Semantics, http://www.hf.uib.no/forskerskole/new_frames_intro.pdf (14.04.2009).

Goldberg, A. E., 1995, Constructions. A Construction Grammar Approach to Argument Structure, Chicago: University of Chicago Press.

Goldberg, A. E., 2003, Constructions: a new theoretical approach to language, "Trends in Cognitive Sciences" 7(5), 219-224.

Goldberg, A. E., 2006, Constructions at work. The nature of generalizations in language, Oxford: Oxford University Press.

Kalisz, R., 2001, Jezzkoznawstwo kognitywne w świetle jezzykoznawstwa funkcjonalnego, Gdańsk: Wydawnictwo Uniwersytetu Gdańskiego.

Kardela, H., 2006, Metodologia językoznawstwa kognitywnego, [w:] P. Stalmaszczyk (red.), 196-233.

Kay, P., Ch. J. Fillmore, 1999, Grammatical Constructions and Linguistic Generalizations: The What's X Doing Y? Construction, "Language" 75(1), 1-33.

Kieraś, W., 2008, Analiza wybranych czasowników polskich w aparacie ram interpretacyjnych, „LingVaria” III 2(6), 155-165 
Lakoff, G., 1987, Women, Fire and Dangerous Things, Chicago and London: The University of Chicago Press.

Lambrecht, K., 1984, Formulaicity, Frame Semantics and Pragmatics in German Binominal Expressions, "Language” 60(4), 753-796.

Langacker, R. W., 2008, Cognitive Grammar. A Basic Introduction, Oxford: Oxford University Press.

Lehrer, A., 1992, Names and Naming: Why We Need Fields and Frames, [in:] A. Lehrer, E. Feder Kittay (ed.), 123-142.

Lehrer, A., E. Feder Kittay (ed.), 1992, Frames, fields and contrasts, Hillsdale, NJ: Lawrence Erlbaum.

Lewandowska-Tomaszczyk, B. (ed.), 1999, Cognitive Perspectives on Language, Frankfurt am Main: Peter Lang.

Neubert, A., G. M. Shreve, 1992, Translation as Text, Kent, Ohio and London: The Kent State University Press.

Petruck, M. R. L., 1995, Frame semantics and the lexicon: Nouns and verbs in the body frame, [in:] M. Shibatani, S. Thompson (ed.), 279-297.

Petruck, M. R. L., 1996, Frame Semantics, [in:] J. Verschueren et al. (ed.), http://framenet. icsi.berkeley.edu/papers/miriamp.FS2.pdf (9.11.2007).

Rojo López, A. M., 2002, Applying Frame Semantics to Translation: A Practical Example, “Meta” XLVII(3), 311-350.

Ruppenhoffer, J., M. Ellsworth, M. L. R. Petruck, C. Johnson, J. Scheffczyk, 2006, FrameNet II: Extended Theory and Practice, http://framenet.icsi.berkeley.edu/index. php?option $=$ com_wrapper\&Itemid $=126$ (20.05.2008).

Shibatani, M., S. Thompson (ed.), 1995, Essays in Semantics and Pragmatics. In honor of Charles J. Fillmore, Amsterdam and Philadelphia: John Benjamins.

Snell-Hornby, M., 2005, Of catfish and blue bananas: scenes-and-frames semantics as a contrastive knowledge system for translation, [in:] H. V. Dam, J. Engberg, H. GerzymischArbogast (eds), 193-206.

Snell-Hornby, M., 2006, The Turns of Translation Studies, Amsterdam and Philadelphia: John Benjamins.

Stalmaszczyk, P. (red.), 2006, Metodologie językoznawstwa. Podstawy teoretyczne, Łódź: Wydawnictwo Uniwersytetu Łódzkiego.

Stockwell, P., 2006, Schema theory: stylistic applications, [in:] K. Brown (ed.), vol. 11, 8-13.

Szymańska, I., G. Śpiewak, 2006, Gramatyka konstrukcji — zatożenia teoretyczne i pytania metodologiczne, [w:] P. Stalmaszczyk (red.), 174-195.

The Linguistic Society of Korea (ed.), 1982, Linguistics in the Morning Calm, Seoul: Hahnsin Publishing Co.

Tokarski, R., 2006, Pola znaczeniowe i ramy interpretacyjne - dwa spojrzenia na jezzk, „LingVaria” 1(1), 35-46.

Verschueren, J., J.-O. Östman, J. Blommaert, C. Bulcaen (ed.), 1996, Handbook of Pragmatics, Philadelphia: John Benjamins.

Waszakowa, K., 1998, Neologizmy tekstowe w świetle ram interpretacyjnych, [w:] J. Bartmiński, B. Boniecka (red.), 21-33.

Zampolli, A. (ed.), 1977, Linguistic Structures Processing, Amsterdam: North Holland.

Zawisławska, M., 1998, Rama interpretacyjna jako narzędzie analizy tekstu, [w:] J. Bartmiński, B. Boniecka (red.), 34-44.

Projekt „FrameNet”:

http://framenet.icsi.berkeley.edu/index.php?option=com_frontpage\&Itemid=1

Projekt „Ramki” dla języka polskiego:

www.ramki.uw.edu.pl 